Collection: IUFRO RG 7.01 (2010) - Antalya (Turkey)

Adaptation of Forest Ecosystems to Air Pollution and Climate Change

Guest Editors: Elena Paoletti, Yusuf Serengil

\section{Genetic monitoring in forests - early warning and controlling system for ecosystemic changes}

\begin{abstract}
Konnert $M^{(1)}$, Maurer W ${ }^{(2)}$, Degen $B^{(3)}$, Kätzel R ${ }^{(4)}$
In the context of existent programmes of environmental monitoring which have been established as efficient tools for permanently observing environmental changes, a concept for a genetic monitoring in forests was recently elaborated by a German forest geneticist working group. Genetic monitoring is assumed to contribute essentially to the estimation and valuation of the effect of factors influencing the genetic system of trees in the forests, thus making it an early warning and controlling system for ecosystemic changes. The "Concept of a Genetic Monitoring for Forest Tree Species in the Federal Republic of Germany" gives scientifically-based guidelines for monitoring the current state and dynamics of genetic systems in forest stands of diverse tree species in an extensively, harmonized manner. Both objectives and the realization of the genetic monitoring concept are presented here. The status of the genetic systems of forest tree populations is assessed on the basis of criteria, indicators and verifiers. For this purpose the genetic as well as the phenological and physiological levels are taken into consideration in order to follow temporal developments and to estimate influencing factors. The results of a pioneer study concerning the tree species Fagus sylvatica and Prunus avium are reported.
\end{abstract}

Keywords: Genetic monitoring, Fagus sylvatica, Prunus avium, Indicators, Mating system

\section{Introduction}

The conservation of genetic resources is an important issue in managed forests. The adaptability of trees to environmental factors such as climate change or to outbreaks of pests and diseases depends basically on genetic variation. Thus, it is crucial for the maintenance of forests to prevent the erosion of genetic diversity.

Genetic diversity with its inherent extent of allelic and genotypic structures is the elementary base for biological diversity. It is considered to be one of the criteria which are most important for assessing the potential for dramatic and potentially deleterious changes for any forest tree stand during its lifetime. Especially under the present impact of predicted climate change, it is necessary that forest ecosystems with high levels of biodiversity are capable of persisting and surviving. Even more it is an essential prerequisite to safeguard the diverse functions of the forests in a future-oriented way. In this context it is of top priority to maintain genetic diversity and to protect the genetic system of the woody plant species.

The recent increases in temperature resul- ting from global climate change impose a directional selection pressure on the population, which generates a change of the genotype frequencies. An evolutionary response to warming temperatures can be expected (Jump et al. 2006). As a consequence, many efforts are underway presently on the international and national levels to conserve forest genetic resources both in situ and ex situ in a sustainable way. The manifold collaborating activities among different international organizations, programmes and processes like IUFRO, EUFORGEN, the CBDprocess, IPGRI, and some more should be stressed in this context.

Great efforts are practiced also on the level of individual nations. In Germany the "Concept for the Conservation of Forest Genetic Resources" was already introduced in 1987 and was revised thoroughly in 2000 (see http://www.genres.de/fgrdeu/blag). The latter version by Paul et al. (2000) includes expressis verbis for the very first time the target to develop of a long-term genetic monitoring scheme. The long-term potential of survival for genetic reserves should also be assessed (Broadmeadow \& Ray 2005).
(1) Bayerisches Amt für forstliche Saatund Pflanzenzucht, Forstamtsplatz1, D83317 Teisendorf (Germany); (2)

Forschungsanstalt für Waldökologie und Forstwirtschaft Rheinland-Pfalz, Schloss, D67705 Trippstadt (Germany); (3) Institut für Forstgenetik des von Thünen-Instituts, Sieker Landstrasse 2, D-22927 Großhansdorf (Germany); (4) Landesforstanstalt Eberswalde, Fachbereich Waldentwicklung und Monitoring, Alfred-Möller-Strasse 1, D16225 Eberswalde (Germany).

(a) Monika Konnert

(monika.konnert@asp.bayern.de)

Received: May 18, 2010 - Accepted: Sep 19, 2010

Citation: Konnert M, Maurer W, Degen B, Kätzel R, 2011. Genetic monitoring in forests - early warning and controlling system for ecosystemic changes. iForest 4: 77-81 [online: 2011-04-06] URL:

http://www.sisef.it/iforest/show.php? id $=571$

While some diverse environmental monitoring programmes have been established in the past 10 to 15 years as efficient tools for permanently observing environmental changes, genetic aspects are lacking however. Information from monitoring programs could be used to update risk assessments in forest management plans in an adaptive-management sense. The task for the next decade is to understand better how climate affects tree population and how forests respond to them. Improved monitoring programs and analytic tools are needed to develop this understanding (Dale et al. 2001, Spittlehouse \& Stewart 2003).

As a result of this situation a concept for a genetic monitoring scheme in forests was elaborated by a German forest geneticist working group (see BLAG-Expertengruppe "Genetisches monitoring" 2004, BLAG-Expertengruppe "Genetisches Monitoring" 2008; Kätzel et al. 2005, Maurer 2005). This decisive measure is regarded as an essential step towards implementing the Convention on Biological Diversity which in paragraph $7 \mathrm{~b}$ calls for the surveillance of the distinct constituents of biological diversity (Anonymous 1993).

To the best of our knowledge, it is the very first time that a concept for a genetic monitoring in forests was elaborated and tested in pilot studies. Similar considerations exist only for different plant and animal species (Schwartz et al. 2006). However, we do not know whether or not such approaches have been realized in the meantime.

\section{Objectives of a genetic monitoring scheme}

The aim of carrying out a genetic monito- 
ring is to observe the dynamics of transition from the present to the future genetic status of a forest stand. In order to do this, the status of the genetic system must be conceived in its entirety. The genetic system comprises all mechanisms and processes which contribute to the production, the maintenance, and last but not least to the modification of genetic variability and its transfer to the succeeding generations. Initially the essential attributes (characteristics) of this system must be detected. Then parameters or indicators are needed which clearly show whether this system is intact or disturbed, and to what extent. Finally the specific hypotheses are examined using verifiers.

\section{The German concept for genetic monitoring of forest tree species}

\section{Indicators and verifiers}

The intactness (resp. functionality) of the genetic system of a species is characterized by the population genetic processes of selection, mating system and migration. Thus, the maintenance of these processes represents the criteria for conserving genetic variation The German "Concept for Genetic Monitoring in Forests" as published in 2004 by the BLAG-Expertengruppe "Genetisches Monitoring" is based on the indicators proposed by Namkoong et al. (1996) for population genetic processes concerning the following points:

- level of genetic variation;

- directional change in gene or genotypic frequencies;

- changes in mating system processes;

- gene migration between populations.

Genetic monitoring uses these indicators to assess the conditions and the dynamics of the processes of the genetic system by repeating this procedure at different times (Gregorius \& Degen 2007)

For this procedure, common population genetic data and the parameters deduced from this data are estimated. These data represent the verifiers of the given indicators. Tab. 1 summarizes keywords characterizing the verifiers for the respective indicators.

Gene frequencies and different genetic parameters based on gene frequencies, like genetic diversity, number of polymorphic loci, mean number of alleles per locus, variation in bud burst, in frost resistance etc. can be applied efficiently as measures for assessing the level of genetic variation. The outcrossing rate, the number of effective pollen donors, but also the quality of seed reflected by the proportion of empty seed or by germinability supply valuable information about the mating system. Gene migration is verified by the pollen and seed dispersal distance as well as by the presence/absence of family structures within a tree population.

The different verifiers that can be measured

Tab. 1 - Indicators and verifiers of the genetic processes. (P): number of polymorphic loci; (A/L): mean number of alleles per locus; (F-value): fixation index.

\begin{tabular}{ll}
\hline \multicolumn{1}{c}{ Indicators } & \multicolumn{1}{c}{ Verificators } \\
\hline $\begin{array}{l}\text { Level of genetic } \\
\text { variation }\end{array}$ & $\begin{array}{l}\text { Gene frequencies, genetic diversity, } \mathrm{P}, \mathrm{A} / \mathrm{L}, \text { variation in pheno- } \\
\text { logical parameters, F-value, Number of potential parent trees }\end{array}$ \\
\hline $\begin{array}{l}\text { Directional change in gene } \\
\text { or genotypic frequencies }\end{array}$ & $\begin{array}{l}\text { Differences between cohorts: - in allele, genotype and pheno- } \\
\text { type frequencies, - in the distribution of age classes }\end{array}$ \\
\hline $\begin{array}{l}\text { Changes in mating } \\
\text { system processes }\end{array}$ & $\begin{array}{l}\text { Mating system, rate of cross-fertilization, rate of biparental in- } \\
\text { breeding, number of effective pollen donors, proportion of } \\
\text { empty/full seed and germinability }\end{array}$ \\
\hline $\begin{array}{l}\text { Gene migration between } \\
\text { populations }\end{array}$ & $\begin{array}{l}\text { Dispersion of pollen and seeds, differentiation between popula- } \\
\text { tions of the same age, isolation, family structures }\end{array}$ \\
\hline
\end{tabular}

and are used for any indicator differ widely in their individual precision by which they estimate the genetic parameters. And last but not least, they differ in cost and the numbers of facilities required to sample and measure them.

\section{Realization}

Genetic monitoring includes the periodical, randomized or plot-specific inspection of genetic structures and characteristics of the genetic system (e.g., population size, flowering and sexual system). It should be carried out both in managed and unmanaged forests.

The following strategy for carrying out genetic monitoring in practice is proposed in the concept:

- identifying the genotypes of the reproductive trees in the selected monitoring plots or stands through a basic inventory using genetic markers;

- assessing the genetic composition of natural regeneration of an adequate sample from the stand under study; this procedure should be repeated after 10-15 years;

- performing additional inventories periodically to determine the extent of flowering and fructification of selected trees (e.g., every 1-2 years);

- carrying out additional genetic studies on the seeds from different seed years (e.g., every 5 years);

- calculating the given indicators for genetic processes based on the genotypes of the adult trees, natural regeneration and the seeds;

- simulating, the temporal and spatial dynamics of the genetic and demographical composition of tree populations based on empirical monitoring data in order to identify any critical development,

The tree species are chosen according to their importance concerning usability, existence, and indicator capacity. It is recommended to work first on tree species for which genetic markers are available for routine serial tests. For reasons of comparability, genetic monitoring should be performed according to tree species-specific harmonized methods, particularly regarding sampling strategy, inventory procedures, analyzing techniques, documentation, and data evaluation. The data obtained is to be recorded in such a way that it will be useful in simulation processes.

Both managed and unmanaged sites may be used as monitoring plots. A detailed documentation must be made to ensure continuity of the monitoring procedure. The geographic coordinates of the plot, the history of the stands and the treatments carried out should be considered. Furthermore, the geographic coordinates of the individual trees, their quality traits as well as their social classification must be considered. If possible, relevant environmental data like weather, atmospheric pollution, quantity of pollutant input, and soil vegetation should be recorded.

\section{Pilot studies}

\section{Methodological aspects}

In Germany the first practical experiences were gained in a pilot study conducted on European beech (Fagus sylvatica) as an important predominant wind-pollinated species (Maurer et al. 2008) and wild cherry (Prunus avium) as a rare species pollinated by insects (Degen et al. 2008). This study included four beech stands located in north $(\mathrm{N})$, east (E), central (C), and south Germany (S) and five wild cherry populations. The wild cherry stands under study include the stands Einhaus (northern Germany); Chorin (north-eastern Germany); Spargründe (eastern Germany); Hildesheimer Wald (central Germany), and Reutlingen (southern Germany).

Beech - Each experimental beech plot includes a total area of 4 hectares, subdivided into 3 zoned sections which are marked visibly by pegs. There is a central part of $50 \mathrm{x}$ 50 meters ("core section", 0.25 ha), surrounded by a square of $100 \times 100$ meters which is called the "intensive section".

It comprises a total area of 1 ha. Within the core zone particularly additional parameters like flowering phenology, leaf unfolding and nutrient analyses were monitored. Outside of this intensive plot, an area of $200 \times 200$ meters is delimited which is called the "ex- 
tensive section". The overall area is 4 ha (Fig. 1). Sampling of adult trees, natural regeneration and seeds was performed within these different zones at differing intensities.

The collected materials were used for genetic studies and for characterizing the quality structure of beechnut seeds (see Tab. 2). The position of each sample tree was determined exactly by applying for example GPS.

For genetic studies isozyme gene markers as well as molecular genetic markers including microsatellites (SSRs) and Arbitrary Fragment Length Polymorphisms (AFLPs) were applied. Different genetic parameters were calculated reflecting genetic variation (verifiers - see Tab. 1), spatial genetic structures, parameters reflecting the mating system, pollen distribution functions, and parental analysis. Programs used included GDA-NT (Degen 2008), GSED (Gillet 2008), SGS-Spatial Genetic Software (Degen 2001), MLTR-Multilocus Mating System Program (Ritland 2002), PolDisp (Robledo-Arnuncio et al. 2007), and Cervus (Kalinowski et al. 2007).

Random samples of the beechnut seeds collected within the four monitoring plots were tested for their quality structure according to the ISTA regulations (Anonymous 2003). Phenological observations included basically flushing in springtime which was carried out on selected individual trees.

Prunus - Because of its low and variable density, the plot size for Prunus avium was defined as the area that includes 150 reproductive trees. The size of the five wild cherry plots varied from 0.6 ha to 18.1 ha depending on the variable densities of reproductive trees (5 individuals per ha to 230 individuals per ha). In each plot 150 saplings were sampled in a statistically representative way over the whole area. Seeds were collected from at least 30 trees within each plot. The genetic inventories were done by applying nuclear microsatellites, AFLPs and markers for the known locus of the self-incompatibility (S-locus). Furthermore the spatial position, diameter, natural social class, and flowering phenology for of the reproducing trees were measured and the quality of seeds was tested. For computing the genetic parameters the same analysis programs were used as for beech.

\section{First results}

Beech - Except for plot $\mathrm{N}$ the differences in genetic diversity between the three developmental stages of the stands under study were found to be low (see Fig. 2.).

The outcrossing rate exceeded $95 \%$, the number of effective pollen donors was found to be high, at 12 to 63 trees. The maximum pollen dispersal distance varied from 112 to $133 \mathrm{~m}$. Consequently, the mating system appears to be widely intact. Moreover, a high

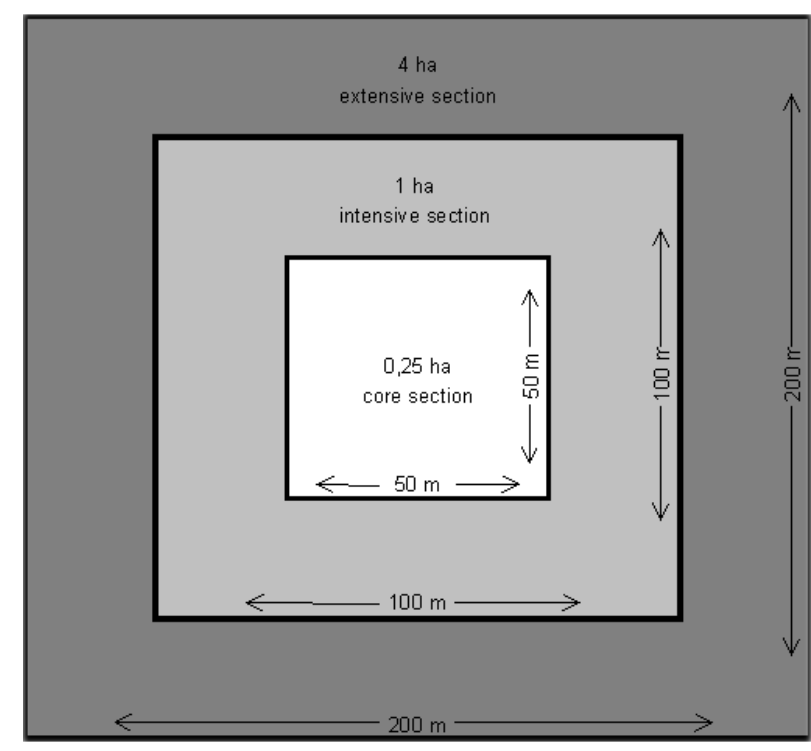

Fig. 1 - Schematic design of a monitoring plot for abundant tree species presenting the arrangement in core, intensive and extensive sections. potential for transmitting genetic information over generations can be assumed. Repeated inventories to be performed in the following years will reveal whether or not this intactness will be sustained.

The four monitoring plots comprise different distinct gene pools which represent each local gene pool well. This observation makes it clear that plots located in different regions must be included when performing a genetic monitoring in order to consider local peculiarities,

Differences in flushing became evident both in the years of observation and in all of the four monitoring plots. In 2006 flushing started earlier in plot $\mathrm{S}$ as compared to plot $\mathrm{E}$, and this process took about six more days. In 2007 flushing started on both plots significantly earlier. These observations will be pursued in the next years in order to make specific evaluations associated with plot-related climate data.

The combination of different indicators and verifiers was used as an approach to assess the intactness of the genetic system. A set of 18 indicators/verifiers was applied according cluded the:

1. level of genetic diversity in the mature to the Concept of Genetic Monitoring. It in- stand verified by the effective numbers of alleles of the analyzed isozymes, SSRs and AFLPs as well as the level of heterozygosity of the isozymes, and flushing;

2. changes in the gene and genotype frequencies verified by estimating the differences between the developmental stages of the trees within a stand and the differences between the cohorts of natural regeneration;

3. mating system verified by a deficit of heterozygous mature individuals as compared to Hardy Weinberg equilibrium (isozymes); open pollination rate; number of effective pollen donors; spatial genetic structures (family structures); and germination percent of the seeds in 2006; and

4. migration verified by the differences between the genetic differentiation of the mature stands studied and its pollen dissemination in 2006.

Each verifier was assigned one of the three values, either -1 , zero $(0)$, or $+1 .+1$ signifies an expected positive effect on the genetic system of the tree population. -1 indicates a negative effect and 0 was assigned in case of incomplete data. The average of all verifiers was used to judge the overall situation of each population. Based on this, the genetic
Tab. 2 - Overview of the sampling procedure to be carried out in the 3 sections of a monito ring plot.

\begin{tabular}{|c|c|c|}
\hline $\begin{array}{l}\text { Developmental } \\
\text { state }\end{array}$ & $\begin{array}{c}\text { Intensive section } \\
\text { including core section }\end{array}$ & Extensive section \\
\hline \multicolumn{3}{|l|}{ Genetic Studies } \\
\hline adult trees & all individuals present & additional individuals up to max. 300 \\
\hline \multirow[t]{2}{*}{ natural regeneration } & 200 young plants representative fo & or the overall plot \\
\hline & $\begin{array}{l}4 \text { clusters of natural regeneration } \\
\text { comprising } 50 \text { individuals each }\end{array}$ & - \\
\hline beechnuts seeds & collecting per individual tree separ & rately beechnuts from 20 adult trees \\
\hline \multicolumn{3}{|c|}{ Quality structure of beechnut seeds } \\
\hline beechnuts seeds & seed mixture of the overall stand & \\
\hline
\end{tabular}




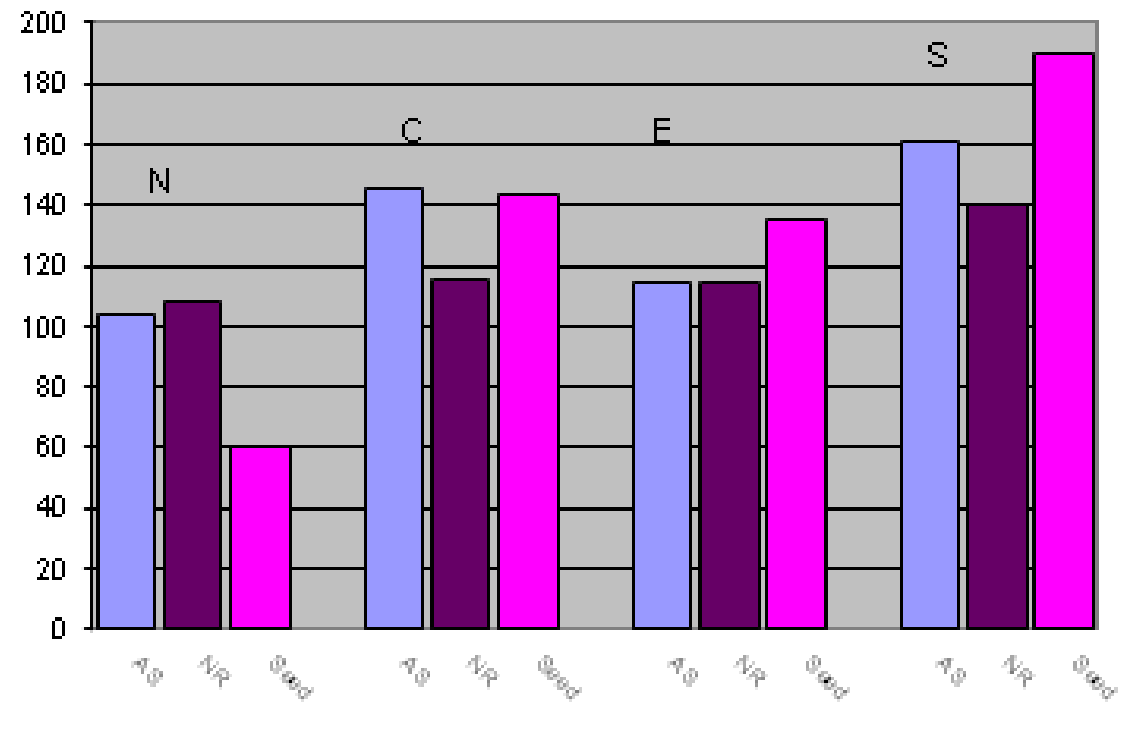

Fig. 2 - Genetic diversity (expressed as vgam) as determined in the four beech monitoring plots for the adult stand (AS), natural regeneration (NR) and the seeds.

system present now was appraised undisturbed for two out of the four monitoring plots (plot $\mathrm{N}$ and plot $\mathrm{S}$ ). No clear statement could be made for plot E. Therefore clarity must be obtained by carrying out another survey. For plot $\mathrm{C}$ however which was severely affected by strong wind attacks, the actual status of the genetic system must be judged to be in critical conditions

Prunus - The results obtained show significant differences in the level of genetic diversity, genetic differentiation and spatial genetic structure. In all cases the genetic differences among stages of different stands were significantly larger $(20-40 \%)$ than the

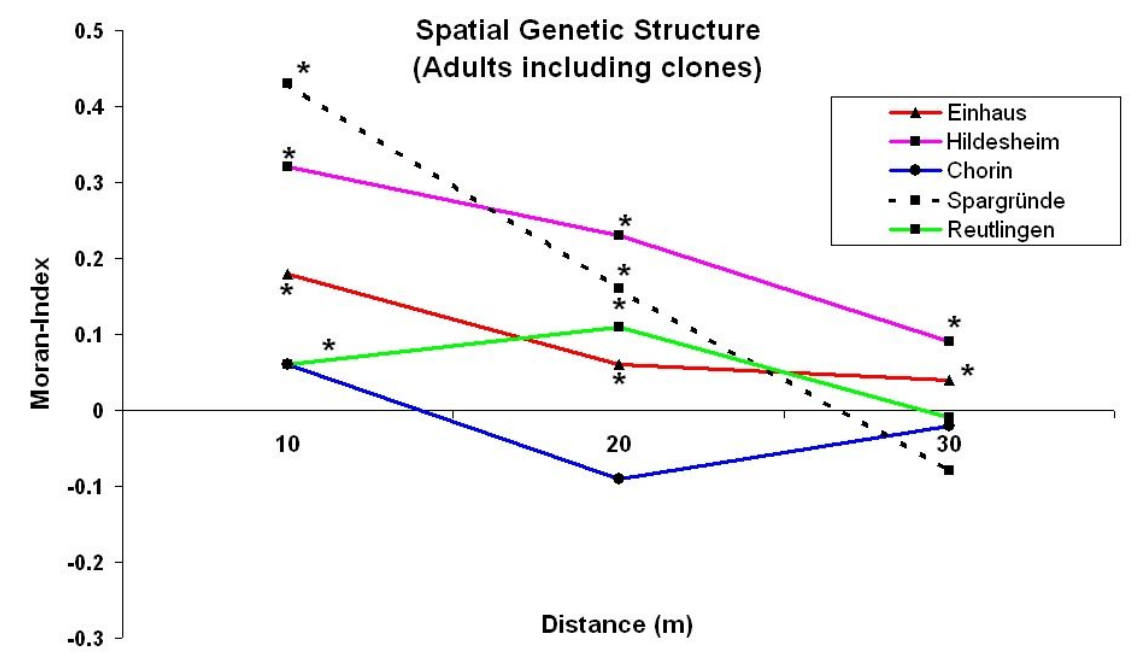

Fig. 3 - Moran-index of the adult trees for four microsatellites as determined in the five wild cherry monitoring plots by including all trees growing within the plots; $\left(^{*}\right)$ : significant on 95 $\%$ level. trees per ha to 230 adult trees per ha. The distances of seed dispersal were found to be independent from of the tree densities. Pollen dispersal however was partly controlled by densities and even more by the extension of clonal groups. Due to the self-incompatibility system auto-fertilization was impossible for trees presenting the same clone.

For the Moran's index which gives information of the so-called spatial autocorrelation, significantly positive values in four out of the five plots under study were obtained for the first three distance classes up to $30 \mathrm{~m}$ (see Fig. 3). The bulk of these spatial genetic structures most probably results from the clones present.

The genotypes of the adult populations and the estimates of population-genetic processes were integrated into the simulation model Eco-Gene. The simulations predicted the dynamics of genetic structures and supported defining thresholds for critical changes in the genetic composition of the wild cherry populations. A set of 13 indicators and verifiers was tested according to the Concept of $\mathrm{Ge}$ netic Monitoring to estimate the intactness of the genetic system of the five stands under study. For the indicator "level of genetic diversity" the effective numbers of genetic variants (alleles) in the three types of studied gene markers were used as verifiers. To verify the indicator "mating system": (a) in accordance with Hardy-Weinberg proportions; (b) effective distances of pollen dispersal; (c) proportion of clones; (d) presence of family structures; (e) number of different S-alleles for the gene locus which controls the self-incompatibility of pollen; and (f) the germination percentage of seeds was taken into account. The indicator "genetic drift and directional change of genetic structure" was evaluated using the verifiers: (a) genetic differences among different ontogenetic stages of the same stand; (b) risk of hybridization with cultural cherry trees; and (c) population size. Like for beech each verifier got one of the three values -1 , or Zero $(0)$ or +1 . The average of all verifiers was used to assess the overall situation of each population. This allowed a clear ranking among the stands concerning the quality, i.e., intactness of the genetic system.

\section{Conclusions}

In a holistic approach genetic monitoring includes genetic and phenological as well as physiological aspects of equal significance for characterizing the genetic system of tree populations. It is in fact an early warning and controlling system, because changes in the stand structure, vitality and natural regeneration often proceed with concomitant changes of the genetic system, which are usually not immediately observable. The results of the genetic monitoring supply information on the current state of the genetic system of the 
forest tree species under surveillance. Moreover, they are judged to be useful for estimating genetic implications of silvicultural measures; for developing practical strategies concerning the conservation of forest genetic resources; for integrating genetic aspects in the strategic utilization of different monitoring programmes as well as for optimizing the genetic management in view of the sustainable utilization of forest ecosystems.

The two pilot studies carried out gave first important practical experiences. Moreover, they reveal the necessity and urgency to initiate genetic monitoring promptly by considering different tree species. And finally genetic monitoring should be performed coordinated both on the national and the international level.

It cannot be answered presently whether or not all indicators examined deserve the same weighting. Further research in this context is absolutely necessary. With these case studies, the first proper monitoring of plots with a rich genetic data pool was initiated. The genetic monitoring of the plots presented here will be continued in the future.

\section{Acknowledgement}

The authors wish to thank all the members of the BLAG-Expertengruppe "Genetisches Monitoring", especially Ute Tröber, Eva Cremer, Aikaterini Dounavi, Celine Jolivet, and Winfried Steiner as well as all other colleagues who contributed to the overall project with their target-oriented work and cooperative dedication. They also appreciate the competence and skilfulness of the lab personnel. And last but not least they are obliged to the Bundesamt für Landwirtschaft und Ernährung (BLE; Federal Agency for Agriculture and Food) in Bonn (Germany) for funding the projects (Az. 514-73.01/ 05BE003/1 and 05/BE003/2).

\section{References}

Anonymous (1993). Convention on Biological Diversity in Rio 1992. [online] URL: http://www.biodiv.org/convention/

Anonymous (2003). ISTA the international rules for seed testing. (International Seed Testing Association ed). Single paper collection with amendments 2004, 2005, 2006. Bassersdorf, Switzerland.

BLAG-Expertengruppe "Genetisches monitoring"
(2004). Concept on the genetic monitoring for forest tree species in the federal republic of Germany. [online] URL: http://blag.fgr.genres.de/genetisches-monitoring/index.htm

BLAG-Expertengruppe "Genetisches Monitoring" (2008). Anleitung zur Durchführung des genetischen Monitorings für bestandesbildende Baumarten. [online] URL: http://blag.fgr.genres.de/ publikationen/gm-durchfuehrung 260308.pdf

Broadmeadow M, Ray D (2005). Climate change and British woodland. Information Note 69, Forestry Commission, Edinburgh, United Kingdom.

Dale VH, Joyce LA, McNulty S, Neilson RP, Ayres MP, Flannigan MD, Hanson PJ, Irland LC, Lugo AE, Peterson CJ, Simberloff D, Swanson FJ, Stocks BJ, Wotton BM (2001). Climate change and forest disturbances. BioScience. 51: 723-734. - doi: 10.1641/0006-3568(2001)051 [0723:CCAFD]2.0.CO;2

Degen B (2001). SGS - Spatial Genetic Software, Version 1.0 c. Computer software. [online] URL: http://software.bfh-inst2.de/software.html

Degen B (2008). Computer Program GDA_NT Genetic data analysis and numerical tests. Version 2, May 2008

Degen B, Jolivet C, Liesebach H, Hoeltken A, Dounavi A, Fladung M, Naujoks G, Schneck V, Stauber Th, Steiner W, Köhl M (2008). Erfassung genetischer Strukturen wichtiger Waldbaumarten, Teillos 2: Erfassung der genetischen Struktur der Vogelkirsche (Prunus avium) als Grundlage für ein genetisches Monitoring wichtiger Waldbaumarten in Deutschland. Endbericht BLE-Projekt-Nr. 05/BE003/2, pp. 56.

Gillet EM (2008). Computer program GSED - Genetic structures from electrophoretic data. [online] URL: http://www.uni-forst.gwdg.de/forst/ $\mathrm{fg} /$ index.htm

Gregorius HR, Degen B (2007). Monitoring genetischer Ressourcen - Prinzipien und Methoden. In: Proceedings of the conference "Monitoring und Indikatoren der Agrobiodiversität" (Begemann et al. Eds). Königswinter (Germany) 7-8 November 2006, pp. 39-65.

Jump AS, Hunt JM, Martinez-Izquierdo JA, Penuelas J (2006). Natural selection and climate change: temperature-linked spatial and temporal trends in gene frequency in Fagus sylvatica. Molecular Ecology 15: 3466-3480. - doi: 10.1111/ j.1365-294X.2006.03027.x

Kalinowski ST, Taper ML, Marshall TC (2007). Revising how the computer program CERVUS accommodates genotyping error increases success in paternity assignment. Molecular Ecology
16: 1099-1006. - doi: 10.1111/j.1365-294X.2007. 03089.x

Kätzel R, Maurer WD, Konnert M, Scholz F (2005). Genetisches Monitoring in Wäldern. Forst und Holz 5:179-183.

Maurer WD (2005). Genetisches Langzeitmonitoring im Wald unter Berücksichtigung von in-situund ex-situ-Erhaltungsmaßnahmen. In: "ZADI-Schriften zu genetischen Ressourcen” (Begemann F, Schröder S, Weigand S eds), vol. 24, pp. 82-90.

Maurer WD, Cremer E, Degen B, Konnert M, Tröber U (2008). Erfassung genetischer Strukturen wichtiger Waldbaumarten, Teillos 1: Erfassung der genetischen Struktur der Rotbuche (Fagus sylvatica) als Grundlage für ein genetisches Monitoring wichtiger Waldbaumarten in Deutschland. Endbericht BLE-Projekt-Nr. 05/BE003/1, pp. 81.

Namkoong G, Boyle T, Gregorius HR, Joly H, Savolainen O, Ratnam W, Young A (1996). Testing criteria and indicators for assessing the sustainability of forest management: genetic criteria and indicators. CIFOR Working Paper 10, Center for International Forestry Research, Bogor, Indonesia. - [online] URL: http://www.cifor.cgiar.org/ Publications/DocumentDownloader

Paul M, Hinrichs A, Janssen A, Schmitt HP, Soppa B, Stephan BR, Dörflinger H (2000). Concept for the conservation and sustainable utilization of forest genetic resources in the Federal Republic of Germany (Sächs. Landesanstalt für Forsten eds). English translation: Maurer W, Ruetz W. German version published. [online] URL: http://blag.fgr.genres.de/publikationen/fgrkonzept-2000.pdf

Ritland K (2002). Extensions of models for the estimation of mating systems using $n$ independent loci. Heredity 88: 221-228. [online] URL: http://genetics.forestry.ubc.ca/ritland/programs.html

Robledo-Arnuncio JJ, Austerlitz F, Smouse P (2007). PolDisp - Software package to estimate pollen dispersal. Computer software. [online] URL: http://poldisp.googlepages.com/

Schwartz MK, Luikart G, Waples RS (2006). Genetic monitoring as a promising tool for conservation and management. Trends in Ecology and Evolution 22: 25-33. - doi: 10.1016/j.tree.2006. 08.009

Spittlehouse DL, Stewart RB (2003). Adaptation to climate change in forest management. BC Journal of Ecosystems and Management 4 (1): 111. [online] URL: http://www.forrex.org/jem/ 2003/vol4/no1/art1.pdf 